\title{
PERBANDINGAN PENYELESAIAN SENGKETA KONSUMEN DI INDONESIA DENGAN NEGARA-NEGARA COMMON LAW SYSTEM
}

\author{
Kurniawan $^{1}$
}

\begin{abstract}
Since year 2001 in Indonesia based on instruction article 49 subsection (1) the Law number 8 year 1999 of consumer protection have been establishment of Consumer Dispute solution Body (BPSK). Based on degree of President number 90 year 2001 about formation of BPSK in several city in Indonesia. In several country that submit Common Law System dispute solving cases finishing by institute that called Small claims Court and Small Claim tribunal. The difference dispute solving of BPSK with dispute solving by means of the Small Claims Court and Small Claims Tribunal (SCT) is BPSK form of institute consumer dispute solution with small scale, formal and cheap cost, but not limiting large of claim that the consumer offer. Whereas the Small Claims Tribunal bringing limitation with transparant about claim that the offering by consumer. On the Small Claims Court (SCC) committe of solving cases willborn from active judge unsure, and pensioner, whereas in BPSK committe willborn from government unsure, producer and consumer with different background.
\end{abstract}

Keywords: dispute consumer, BPSK, SCT, SCC

\begin{abstract}
Abstrak
Sejak tahun 2001, di Indonesia sesuai dengan amanat Pasal 49 ayat (1) Undang-Undang No. 8 Tahun 1999 tentang Perlindungan Konsumen, telah dibentuk Badan Penyelesaian Sengketa Konsumen (BPSK) berdasarkan Keputusan Presiden Nomor 90 Tahun 2001 tentang Pembentukan BPSK pada beberapa kota di Indonesia. Di beberapa Negara yang menganut Common Law System, kasus-kasus sengketa konsumen diselesaikan oleh lembaga yang disebut The Small Claims Court (SCC) dan The Small Claims Tribunal (SCT). Perbedaan penyelesaian melalui BPSK dengan SCC dan SCT adalah BPSK menyelesaikan sengketa konsumen yang berskala kecil, formal dan biaya murah, namun tidak membatasi besar gugatan yang diajukan konsumen, sedangkan SCT memberikan batasan yang jelas mengenai gugatan yang dapat diajukan oleh konsumen. Pada penyelesaian model SCC, majelis yang menyelesaikan perkara berasal dari unsur hakim aktif dan pensiunan, sedangkan pada BPSK majelis berasal dari unsur pemerintah, pelaku usaha dan konsumen dengan latar belakang yang berbeda-beda.
\end{abstract}

1 Penulis adalah Dosen Fakultas Hukum Universitas Mataram, NTB. Alamat korespondensi: kurniawan3377@yahoo.co.id. 
Kata kunci: Sengketa konsumen, BPSK, SCT, SCC.

\section{Pendahuluan}

Kemajuan ilmu pengetahuan, teknologi komunikasi dan informatika saat ini turut mendukung perluasan ruang gerak masyarakat dalam melakukan transaksi barang dan/jasa hingga melintasi batas-batas wilayah suatu negara, bahkan penawan suatu barang dan/atau jasa oleh pelaku usaha saat ini dilakukan melalui dunia maya (internet) atau yang lebih dikenal dengan electronic commerce atau e-commerce. Kondisi demikian pada satu sisi sangat bermanfaat bagi kepentingan konsumen karena kebutuhannya akan barang dan/atau jasa yang diinginkan dapat terpenuhi serta semakin terbuka lebar kebebasan untuk memilih aneka jenis kualitas barang dan/atau jasa sesuai dengan kemampuannya. Namun disatu sisi, terjadi persoalan-persoalan yang berujung pada sengketa berkaitan dengan transaksi tersebut juga tidak dapat dihindari.

Perkembangan penyelesaian sengketa beberapa tahun terakhir ini tampaknya tidak hanya terjadi pada masyarakat yang sedang berkembang, akan tetapi terjadi juga pada kehidupan masyarakat yang sudah maju atau modern. Penyelesaian sengketa melalui Pengadilan tampaknya kurang memperoleh kepercayaan yang penuh dari masyarakat, dan orang mulai mencari berbagai alternatif penyelesaian sengketa di luar pengadilan.

Semenjak tahun 1970-an di Amerika Serikat terjadi kecenderungan untuk "menciptakan" lembaga alternatif penyelesaian sengketa yang disebut dengan Alternatif Dispute Resolution (ADR) di luar proses peradilan umum. Kecenderungan adanya lembaga alternatif dalam penyelesaian sengketa di luar proses pengadilan berkaitan dengan adanya pandangan bahwa tidak semua masalah atau sengketa yang terjadi cocok atau dapat diselesaikan melalui jalur/proses pengadilan. Trubek mengemukakan bahwa terdapat beberapa sengketa yang kurang cocok diselesaikan melalui proses pengadilan seperti sengketa keluarga, sengketa kontroversi antar tetangga, tuntutan yang mencakup sejumlah uang yang tidak banyak, masalah yang timbul dalam manajemen hubungan perdagangan jangka panjang. ${ }^{2}$

Erman Suparman mengemukakan, penggunaan sistem peradilan modern sebagai sarana pendistribusian keadilan terbukti menjumpai sangat banyak hambatan. Adapun yang menjadi faktor penyebab adalah karena peradilan modern sarat dengan beban formalitas, prosedur, birokrasi serta metodologi yang ketat. Oleh karena itu keadilan yang didsitribusikan melalui lembaga peradilan diberikan melalui keputusan birokrasi bagi kepentingan umum

\footnotetext{
2 Trubek dalam Mochamad Munir, Penggunaan Pengadilan Negeri Sebagai Lembaga Untuk Menyelesaikan Sengketa Dalam masyarakat (Disertasi Universitas Airlangga Surabaya), 1997, hal. 90.
} 
karenanya cenderung berupa keadilan yang rasional. Oleh sebab itu, keadilan yang diperoleh masyarakat modern tidak lain adalah keadilan birokratis. ${ }^{3}$

Penyelesaian sengketa menggunakan pengadilan telah terbukti banyak menimbulkan ketidakpuasan pada pihak-pihak yang bersengketa maupun masyarakat luas. Ketidakpuasan masyarakat dilontarkan dalam bentuk pandangan sinis, mencemooh, dan menghujat terhadap kinerja pengadilan karena dianggap tidak memanusiakan pihak-pihak yang bersengketa, menjauhkan pihak-pihak yang bersengketa dari keadilan, tempat terjadinya perdagangan putusan hakim, dan lain-lain hujatan yang ditujukan kepada lembaga peradilan.

Seiring dengan terjadinya globalisasi, dimana dunia saat ini seperti tanpa batas, menyebabkan Negara-negara di dunia termasuk Indonesia yang memang dari awal masyarakat adatnya telah melaksanakan prinsip-prinsip penyelesaian sengketa damai atau di luar pengadilan dalam kehidupan bermasyarakat mulai memasukkan penyelesaian sengketa di luar pengadilan ini ke dalam ranah hukum positif. Alternatif penyelesaian sengketa di luar pengadilan ini kemudian berkembang dalam menyelesaikan sengketa-sengketa bisnis yang terjadi antara konsumen dengan pelaku usaha.

Berdasarkan uraian latar belakang di atas, maka rumusan masalah yang diangkat dalam tulisan ini adalah bagaimana perbandingan penyelesaian sengketa konsumen di Indonesia dengan di negara-negara yang menganut common law system.

\section{Pembahasan}

\section{Istilah, Pengertian Sengketa dan Sengketa Konsumen}

Istilah sengekta dan konflik acapkali digunakan secara bergantian, namun sejatinya dua terminologi ini memiliki karekteristik yang berbeda. Tidak setiap konflik menimbulkan sengketa, sebaliknya setiap sengketa adalah konflik. ${ }^{4}$ Di dalam kajian psikologi, dikenal jenis konflik kejiwaan yang bukan persengketaan hukum. Hal ini berangkat dari definisi konflik yang diartikan sebagai terjadinya secara bersamaan dua atau lebih influs atau motif yang antagonis. Satu konflik aktual biasanya mempercepat satu krisis mental, dan bisa dibedakan dari konflik dasar (root conflict) yang timbul sejak kanak-kanak. Begitu pula di bidang sosiologi dikenal konflik kelompok (group conflict) dan lain-lain. ${ }^{5}$

\footnotetext{
${ }^{3}$ Eman Suparman, Jurisdiksi Pengadilan Negeri Terhadap Forum Arbitrase Dalam Penyelesaian Sengketa Bisnis Berdasarkan Undang-undang Nomor 30 Tahun 1999, Laporan Hasil Penelitian, Dana DIK UNPAD 2003, hal. 2-3 2008), hal. 9

${ }^{4}$ Abu Rohmad, "Paradigma Resolusi Konflik Agraria", (Semarang: Walisongo Press,
} 
Laura Nader dan Harry Tood membedakan pengertian conflict (perselisihan) dengan dispute (sengketa), bahkan conflict (perselisihan) sendiri dapat dibedakan antara pre-conflict (praperselisihan) dan conflict (perselisihan). Nader dan Todd memberikan pengertian konflik adalah perselisihan yang hanya melibatkan kedua pihak saja, sedangkan sengketa adalah perselisihan antara dua pihak atau lebih yang sudah bersifat terbuka dan penyelesaiannya melibatkan pihak ketiga. ${ }^{6}$

Konflik atau sengketa berasal dari terminologi kata bahasa Inggris conflic, yang berarti persengketaan, perselisihan, percekcokan atau pertentangan. Konflik atau persengketaan tentang sesuatu terjadi antara dua pihak atau lebih. Masyarakat pada saat ini dihadapkan pada beberapa pilihan penyelesaian sengketa, sesuai dengan tingkat kepentingan dan pemenuhan kebutuhan dasarnya dalam mamandang konflik atau sengketa itu sendiri. Konflik atau sengketa dapat diselesaikan melalui mekanisme litigasi, non litigasi maupun advokasi. ${ }^{7}$

Menurut B.N. Marbun, yang dimaksud dengan sengketa adalah pertikaian, perselisihan atau sesuatu yang menyebabkan perbedaan pendapat, pertengkaran, perbantahan, yang bisa meningkat menjadi sengketa hukum. ${ }^{8}$ Sedangkan J.C.T. Simorangkir, et.Al. memberikan pengertian sengketa adalah persoalan atau perkara. ${ }^{9}$

Dari beberapa definsi di atas, tampak bahwa konflik sering disebut dalam kajian sosiologis, sedangkan dalam kajian hukum dan antropologi fokus pada istilah sengketa. Sengketa hukum menjadi istilah baku dalam ilmu hukum, khususnya yang terkait dengan kasus-kasus perdata untuk membedakan dengan tindak pidana dalam perkara pidana.

Sengketa adalah suatu fenomena yang universal yang dapat dijumpai pada setiap masyarakat dengan semua latar belakang. Bagaimana sengketa tersebut diselesaikan, tidak ada suatu bentuk yang seragam, artinya pihak yang bersengketa dapat melakukan berbagai pilihan tindakan dengan tujuan agar sengketa tersebut dapat diselesaikan. ${ }^{10}$

5 Ahmad Ali, "Sosiologi Hukum: Kajian Empiris Terhadap Pengadilan”, (Jakarta: Iblam, 2004), hal. 63.

${ }^{6}$ Laura Nader dan Harry Todd dalam Ihromi, "Beberapa Catatan Mengenai Metode Sengketa yang Digunakan Dalam Antropologi Hukum, dalam Antropologi Hukum ; Sebuah Bunga Rampai”, (Jakarta: Yayasan Obor, 1993), hal. 210-211.

${ }^{7}$ Rachmad Syafa'at, "Mediasi dan Advokasi Konsep dan Implementasinya”, (Malang: Agritek YPN Malang Kerjasama dengan SOFA Press, 2006), hal. 33.

8 B.N. Marbun, "Kamus Hukum Indonesia", Cetakan I, (Jakarta: Pustaka Sinar Harapan, 2006), hal. 285.

${ }^{9}$ J.C.T. Simorangkir, et.al, "Kamus Hukum", Cetakan ke-5, (Jakarta: Bumi Aksara, 1995), hal. 157.

10 Kurniawan, "Hukum Perlindungan Konsumen, Problematika Kedudukan dan Kekuatan Putusan BPSK", (Malang: UB Press, 2011), hal. 44. 
Cristoper W. Moore, membedakan sengketa menjadi 2 (dua), yaitu sebagai berikut: ${ }^{11}$

a. sengketa atau konflik yang tidak realistik (unrealistic conflict), yaitu ketika para pihak bertindak seolah-olah mereka berkonflik, meskipun tidak ada kondisi objektif bagi kelanjutan konflik dan;

b. konflik yang realistik (realictic conflict) merupakan betul-betul berasal dari konflik-konflik interest.

Dalam UUPK No. 8 Tahun 1999, menyebutkan bahwa sengketa konsumen merupakan bagian dari institusi administrasi negara yang mempunyai tugas untuk menyelesaikan sengketa antara pelaku usaha dan konsumen, dalam hal ini adalah BPSK. Pasal 1 butir 11 UUPK menunjukkan bahwa yang dimaksud dengan "sengketa konsumen" adalah sengketa antara pelaku usaha dan konsumen.

\section{Penyelesaian Sengketa Konsumen di Indonesia}

Pada tahun 1999, pemerintah Indonesia mengundangkan UndangUndang Nomor 30 Tahun 1999 tentang Arbitrase dan Alterlatif Penyelesaian Sengketa (APS), dan Undang-Undang No. 8 Tahun 1999 tentang Perlindungan Konsumen (selanjutnya disingkat UUPK). Kemudian diundangkan pula beberapa Undang-Undang lainnya seperti tentang ketenagakerjaan sebagai instrumen penyelesaian sengketa di luar pengadilan di Indonesia.

Pasal 45 ayat (2) UUPK menjelaskan bahwa penyelesaian sengketa konsumen dapat ditempuh melalui pengadilan atau di luar pengadilan berdasarkan pilihan sukarela para pihak yang bersengketa. Sedangkan dalam Pasal 47 UUPK dikemukakan bahwa penyelesaian sengketa konsumen di luar pengadilan diselenggarakan untuk mencapai kesepakatan mengenai bentuk dan besarnya ganti rugi dan/atau mengenai tindakan tertentu untuk menjamin tidak akan terjadi kembali atau tidak akan terulang kembali kerugian yang diderita oleh konsumen. Untuk menyelesaikan sengketa konsumen di luar pengadilan, maka dibentuk BPSK sebagaimana dijelaskan pada Pasal 49 UUPK yaitu "pemerintah membentuk badan penyelesaian sengketa konsumen di daerah tingkat II (sekarang Kabupaten atau Kota) untuk menyelesaikan sengketa konsumen di luar pengadilan".

BPSK pertama kali diresmikan pada tahun 2001, yaitu dengan Keputusan Presiden Republik Indonesia Nomor 90 Tahun 2001 tentang Pembentukan BPSK pada Pemerintah Kota Medan, Kota Palembang, Kota Jakarta Pusat, Kota Jakarta Barat, Kota Bandung, Kota Semarang, Kota Yogyakarta, Kota Surabaya, Kota Malang dan Kota Makassar. Kemudian pada tahun yang sama (2001), pemerintah melalui Menteri

\footnotetext{
${ }^{11}$ Cristoper W. Moore, "The Mediation Process: Practical Strategies for Resolving Conflict”, (Edisi Kedua), (San Francisco: Jossey-Bass Publishers, 1996), hal. 162.
} 
Perindustrian dan Perdagangan mengeluarkan Keputusan Menteri Nomor 350/MPP/Kep/12/2001 tentang Pelaksanaan Tugas dan Wewenang Badan Penyelesaian Sengketa Konsumen (BPSK). ${ }^{12}$

Berikut ini akan diuraikan mengenai penyelesaian sengketa konsumen melalui BPSK berdasarkan UUPK No. 8 Tahun 1999 dan Keputusan Menteri Perindustrian dan Perdagngan Nomor 350/MPP/Kep/12/2001 yaitu sebagai berikut:

\section{a. Permohonan Penyelesaian Sengketa Konsumen}

Secara teknis permohonan Penyelesaian Sengketa Konsumen (PSK) diatur dalam Pasal 15 sampai dengan Pasal 17 Keputusan Menteri Perindustrian dan Perdagangan Nomor 350/MPP/Kep/12/2001 tentang Pelaksanaan Tugas dan Wewenang BPSK, dimana bentuk permohonan pernyelesaian sengketa (PSK) diajukan secara lisan maupun tertulis ke BPSK melalui Sekretariat BPSK setempat oleh konsumen, dalam hal konsumen dirugikan oleh pelaku usaha.

Isi permohonan penyelesaian sengketa konsumen, memuat secara benar dan lengkap tentang:

1) identitas konsumen, ahli waris atau kuasanya disertai bukti diri;

2) nama dan alamat pelaku usaha;

3) barang atau jasa yang diadukan;

4) bukti perolehan, keterangan tempat, waktu dan tanggal perolehan barang atau jasa yang diadukan;

5) saksi-saksi yang mengetahui perolehan barang atau jasa, fotofoto barang atau kegiatan pelaksanaan jasa, bila ada.

Setelah permohonan penyelesaian sengketa konsumen diajukan, maka sekretarian BPSK akan mencatat sesuai dengan format yang ada. Setelah itu permohonan akan dibubuhi tanda tangan dan nomor registrasi dan pemohon diberikan bukti tanda terima permohonan penyelesaian sengketa konsumen. Permohonan penyelesaian sengketa konsumen akan ditolak, apabila :

1) tidak memuat persyaratan-persyaratan isi permohonan penyelesaian sengketa konsumen tersebut;

2) permohonan gugatan bukan merupakan kewenangan dari BPSK.

\footnotetext{
${ }^{12}$ Kurniawan, Penyelesaian Sengketa Konsumen Melalui BPSK di Indonesia (Kajian Yuridis Terhadap Permasalahan dan Kendala-kendala BPSK), "Jurnal Hukum \& Pembangunan Universitas Indonesia”, Tahun Ke-41 No. 3 Juli 2011, hal. 337.
} 


\section{b. Tata Cara Penyelesaian Sengketa Konsumen Melalui BPSK}

Sebagai bagian dari penyelesaian sengketa alternatif (alternative dispute resolution), maka tata cara penyelesaiaan sengketa konsumen melalui BPSK sangat sederhana dan sejauh mungkin dihindari suasana formal.

Berikut ini akan diuraikan prosedur penyelesaian sengketa konsumen melalui BPSK yang terdiri dari 3 (tiga) tahap, yaitu:

\section{1) Tahap Permohonan}

Persyaratan Pengaduan

Setiap konsumen yang dirugikan oleh pelaku usaha dapat mengajukan permohonan penyelesaian sengketa konsumen melalui BPSK terdekat. Permohonan tersebut dapat dilakukan oleh konsumen yang bersangkutan, ahli warisnya, atau kuasanya. Permohonan yang diajukan oleh ahli waris atau kuasanya dilakukan bilamana: $^{13}$

1) Konsumen meninggal dunia;

2) Konsumen sakit atau berusia lanjut, sehingga tidak dapat mengajukan pengaduan;

3) Konsumen belum dewasa (Menurut KUH Perdata)

4) Konsumen warga negara asing.

Permohonan diajukan melalui Sekretariat BPSK dapat dilakukan secara tertulis maupun secara lisan. Apabila permohonan diajukan secara tertulis, maka secretariat BPSK akan memberikan tanda terima kepada pemohon. Sedangkan apabila permohonan diajukan secara lisan, maka Sekretariat BPSK akan mencatat dalam sebuah format yang disediakan secara khusus. Selanjutnya Sekretariat BPSK akan mencatat permohonan tersebut dan dibubuhi tanggal dan nomor register.

Permohonan penyelesaian sengketa konsumen harus memuat secara benar dan lengkap sesuai dengan ketentuan Pasal 16 Kepmen Perindag Republik Indonesia Nomor 350MPP/Kep/12/2001, yakni:

1. nama dan alamat lengkap konsumen, ahli waris atau kuasanya disertai bukti diri;

2. nama dan alamat lengkap pelaku usaha;

3. barang atau jasa yang diadukan;

4. bukti perolehan (bon, faktur, kuitansi dan dokumen bukti lain);

5. keterangan tempat, waktu dan tanggal diperoleh barang atau jasa tersebut diperoleh barang atau jasa tersebut;

6. saksi yang mengetahui barang atau jasa tersebut diperoleh;

13 Deperindag, Pedoman Operasional Badan Penyelesaian Sengketa Konsumen (BPSK). 2003, hal. 6. 
7. foto-foto barang dan kegiatan pelaksanaan jasa (bila ada).

Sedangkan Pasal 16 ayat (2) mengatur secara formal dalam surat panggilan tersebut harus dicantumkan:

1. hari, tanggal, jam, dan tempat persidangan;

2. kewajiban pelaku usaha untuk memberikan jawaban terhadap permohonan Penyelesaian Sengketa Konsumen (PSK)

Apabila permohonan ternyata tidak lengkap (sesuai dengan ketentuan Pasal 16 tersebut di atas) atau gugatan bukan merupakan kewenangan BPSK, maka ketua BPSK harus menolak permohonan tersebut. Jika permohonan diterima (memenuhi persyaratan), maka konsumen dan pelaku usaha dapat memilih dan menyepakati cara penyelesaian melalui konsiliasi, mediasi atau arbitrase.

Tidak semua pengaduan konsumen dapat diterima oleh BPSK. Ada beberapa bentuk pengaduan yang tidak dapat diterima oleh BPSK, yaitu apabila:

1. pengaduan tersebut tidak disertai dengan bukti-bukti yang benar;

2. tidak mengisi formulir pengaduan secara lengkap dan benar;

3. sengketa yang diadukan bukan merupakan kewenangan BPSK;

4. pengadunya bukan konsumen akhir (end users);

5. pengaduan yang bersifat class action;

6. pengaduan yang bersifat legal standing; atau

7. pengaduan yang dilakukan oleh pelaku usaha.

Pasal 26 ayat (1) Kepmenperindag No. 350/MPP/Kep/12/2001 menentukan bahwa pemanggilan pelaku usaha untuk hadir di persidangan BPSK, dilakukan secara tertulis oleh Ketua BPSK disertai dengan copy permohonan Penyelesaian Sengketa Konsumen (PSK) dalam waktu 3 (tiga) hari kerja sejak permohonan PSK diterima secara lengkap dan benar telah memenuhi persyaratan Pasal 16 Menperindag No. 350/MPP/Kep/12/2001.

\section{2) Tahap Persidangan}

Penyelesaian sengketa konsumen oleh BPSK dilakukan oleh Majelis yang dibentuk berdasarkan Keputusan Ketua BPSK dan dibantu oleh Panitera. ${ }^{14}$ Majelis tersebut harus berjumlah ganjil dan paling sedikit terdiri dari 3 (tiga) anggota BPSK yang mewakili unsur Pemerintah (sebagai ketua) dan unsur konsumen dan pelaku usaha sebagai anggota. ${ }^{15}$ Sedangkan Panitera ditunjuk dari anggota Sekretariat BPSK. ${ }^{16}$

14 Deperindag, Pedoman Pembentukan Badan Penyelesaian Sengketa Konsumen (BPSK). 2002, hal. 22. 
Jika permohonan diterima, maka Ketua BPSK harus memanggil pelaku usaha secara tertulis disertai dengan salinan permohonan dari konsumen, selambat-lambatnya 3 (tiga) hari kerja sejak permohonan penyelesaian sengketa konsumen diterima secara benar dan lengkap. Untuk keperluan pemanggilan pelaku usaha tersebut, dibuat surat panggilan yang memuat: hari, tanggal, jam dan temapat persidangan serta kewajiban pelaku usaha untuk memberikan surat jawaban terhadap penyelesaian sengketa konsumen dan disampaikan selambat-lambatnya pada hari ke-7 (ketujuh) terhitung sejak diterimanya permohonan oleh BPSK. ${ }^{17}$

Pasal 52 ayat (4) UUPK jo. Pasal 26 sampai Pasal 36 SK Menperindag No. 350/MPP/Kep/12/2001, menjelaskan bahwa penangan dan penyelesaian sengketa konsumen melalui Badan Penyelesaian Sengketa Konsumen (BPSK) dilakukan dengan 3 (tiga) cara, yaitu:

a. Persidangan dengan cara Konsiliasi; atau

b. Persidangan dengan cara Mediasi; atau

c. Persidangan dengan cara Arbitrase.

Berikut ini akan diuraikan satu persatu mengenai ketiga cara penyelesaian sengketa konsumen melalui BPSK, yaitu sebagai berikut:

\section{a. Persidangan dengan cara Konsiliasi}

Untuk menangani penyelesaian sengketa konsumen dengan cara konsiliasi ditempuh atas inisitaif salah satu pihak atau para pihak, sedangkan majelis BPSK bersifat pasif. Majelis BPSK bertugas sebagai perantara antara pihak yang bersengketa. Pada persidangan dengan cara mediasi, maka yang berwenang untuk menetapkan siapa yang menjadi personilnya baik sebagai ketua majelis yang berasal dari unsur pemerintah maupun anggota majelis berasal dari unsur konsumen dan unsur pelaku usaha adalah ketua BPSK.

Penyelesaian dengan konsiliasi, seorang konsiliator akan mengklarifikasikan masalah-masalah yang terjadi dan bergabung di tengah-tengah para pihak., namun posisinya kurang aktif dibandingkan dengan seorang mediator dalam menawarkan pilihanpilihan (option) penyelesian suatu sengketa. Konsiliasi menyatakan secara tidak langsung suatu kebersamaan para pihak dimana pada akhirnya kepentingan-kepentingan bergerak mendekat (moving closer) dan selanjutnya dicapai suatu penyelesaian yang memuaskan kedua belah pihak (a measure of googwill).

\footnotetext{
${ }^{15}$ UUPK. No.8 Tahun 1999, Pasal 54 Ayat (2).

${ }^{16}$ Deperindag, Op.Cit., hal. 23.

${ }^{17}$ Ibid.
} 
Rekonsiliasi menyatakan secara tidak langsung kebersamaan para pihak yang bersengketa dahulunya berkawan atau berkongsi, kini mereka berselisih/bertengkar. Pandangan-pandangan yang berbeda coraknya diantara para pihak harus dipertemukan dengan teliti.

Pasal 28 kepmenperindag No.350/MPP/Kep/12/2001, menyatakan penyelesaian sengketa dengan cara konsiliasi, Majelis (konsiliator) mempunyai tugas sebagai berikut, yaitu

1) memanggil konsumen dan pelaku usaha yang bersengketa;

2) memanggil saksi dan saksi ahli bila diperlukan;

3) menyediakan forum bagi kosumen dan pelaku usaha yang bersengketa;

4) menjawab pertanyaan konsumen dan pelaku usaha, perihal peraturan perundang-undangan di bidang perlindungan konsumen.

Selama proses penyelesaian sengketa, alat bukti (barang dan/atau jasa, keterangan para pihak, keterangan saksi dan atau saksi ahli, surat dan atau dokumen, bukti-bukti lain yang mendukung dapat diajukan oleh Majelis atas permintaan pihak yang bersengketa.

Hasil musyawarah yang merupakan kesepakatan antara konsumen dan pelaku usaha yang bersengketa selanjutnya dibuat dalam bentuk perjanjian tertulis yang ditandatangani oleh para pihak yang bersengketa, selanjutnya diserahkan kepada Majelis untuk dibuat sebuah Putusan BPSK untuk menguatkan perjanjian tersebut.

\section{b. Persidangan dengan cara Mediasi}

Penyelesaian dengan cara mediasi tidak jauh berbeda dengan cara konsiliasi dimana cara ini yang ditempuh atas inisiatif salah satu pihak atau para pihak. Bedanya dengan konsiliasi adalah Majelis BPSK bersifat aktif sebagai perantara dan penasehat. Pada dasarnya mediasi adalah suatu proses dimana pihak ketiga (pihak netral) mengajak pihak yang bersengketa pada suatu penyelesaian sengketa yang disepakati. Sesuai dengan batasan-batasan mediator berada di tengah dan tidak memihak pada salah satu pihak. Sesuai dengan sifatnya, mediasi tidak dapat diwajibkan (compulsory) tetapi hanya dapat terjadi jika kedua belah pihak secara sukarela berpartisifasi. Peran utama mediator adalah memantapkan garisgaris komunikasi dan dialog (lines of communication and dialogue) diantara kedua belah pihak yang akan mengantarkan pemahaman kebersamaan yang lebih besar (greater mutual understanding). Pada akhirnya suatu kesepakatan akan tercipta tanpa cara-cara merugikan (nonviolent means), setidaknya suatu hubungan baik (relationship) tercipta tanpa konflik. 
Pasal 30 Kepmenperindag Nomor. 350/MPP/Kep/12/ 2001, persidangan dengan cara mediasi, Majelis (mediator) mempunyai tugas:

1) memanggil konsumen dan pelaku usaha yang bersengketa;

2) memanggil saksi dan saksi ahli bila diperlukan;

3) menyediakan forum bagi konsumen dan pelaku usaha yang bersengketa;

4) secara aktif memberikan saran dan anjuran penyelesaian konsumen sesuai dengan peraturan perundang-undangan di bidang perlindungan konsumen;

5) secara aktif mendamaikan konsumen dan pelaku usaha yang bersengketa.

Selama proses penyelesaian sengketa, alat bukti (barang dan/atau jasa, keterangan para pihak, keterangan saksi dan atau saksi ahli, surat dan atau dokumen, bukti-buti lain yang mendukung) dapat diajukan oleh Majelis atas permintaan pihak yang bersengketa.

Hasil musyawarah yang merupakan kesepakatan antara konsumen dan pelaku usaha yang bersengketa selanjutnya dibuat dalam bentuk perjanjian tertulis yang ditandatangani oleh para pihak yang bersengketa, selanjutnya diserahkan kepada Majelis untuk dibuat sebuah Putusan BPSK untuk menguatkan perjanjian tersebut.

\section{c. Persidangan dengan cara Arbitrase}

Cara penyelesaian sengketa konsumen dengan cara arbitrase berbeda dengan dua cara penyelesaian sengketa yang ada (mediasi dan konsiliasi). Majelis yang akan menyelesaikan sengketa konsumen dengan cara arbitrase, ketua BPSK tidak berwenang untuk menentukan siapa yang akan menjadi ketua majelis dan anggota majelis. Adapun yang berwenang menentukan siapa yang duduk di majelis adalah para pihak yang bersengketa, para pihak dapat memilih arbiter yang mewakili kepentingannya. Konsumen berhak memilih dengan bebas salah satu dari anggota BPSK yang berasal dari unsur konsumen sebagai arbiter yang akan menjadi anggota majelis. Demikian juga, pelaku usaha berhak memilih salah satu dari anggota BPSK yang berasal dari unsur pelaku usaha sebagai arbiter, yang akan menjadi anggota majelis. (Pasal 32 kepmenperindang No. 350/MPP/Kep/12/2001)..

Selanjutnya, arbiter hasil pilihan konsumen dan arbiter hasil pilihan pelaku usaha secara bersama-sama akan memilih arbiter ketiga yang berasal dari unsur pemerintah dari anggota BPSK yang akan menjadi ketua majelis. Selama proses penyelesaian sengketa, alat bukti (barang dan/tau jasa, keterangan para pihak, keterangan saksi dan tau saksi ahli, surat dan atau dokumen, bukti-bukti lain 
yang mendukung) dapat diajukan oleh Majelis atas permintaan para pihak yang bersengketa. Sekalipun dalam proses penyelesaian sengketa konsumen beban pembuktian ada pada pelaku usaha, namun pihak konsumen pun berhak mengajukan bukti untuk mendukung gugatannya.

Setelah mempertimbangkan pernyataan dari kedua belah pihak mengenai hal yang dipersengketakan dan mempertimbangkan hasil pembuktian serta permohonan para pihak, maka Majelis akan membuat Putusan BPSK.

\section{3) Tahap Putusan}

Majelis wajib menyelesaikan sengketa konsumen selambatlambatnya dalam waktu 21 hari kerja terhitung sejak gugatan diterima BPSK. Hasil penyelesaian sengketa konsumen dengan cara konsiliasi atau mediasi dibuat dalam perjanjian tertulis yang ditandatangani oleh konsumen dan pelaku usaha, selanjutnya dikuatkan dengan putusan Majelis yang ditandatangani oleh Ketua dan Anggota Majelis. Putusan Majelis dalam konsiliasi dan mediasi tidak memuat sanksi administratif. Sedangkan hasil penyelesaian sengketa konsumen dengan cara arbitrase dibuat dengan putusan Majelis yang ditandatangani oleh Ketua dan Anggota Majelis. Putusan Majelis dalam arbitrase memuat sanksi administratif. Putusan Majelis sedapat mungkin didasarkan atas musyawarah untuk mencapai mufakat, namun jika telah diusahakan sungguhsungguh ternyata tidak menghasilkan kata mufakat, maka putusan diambil dengan suara terbanyak (voting). Putusan Majelis tersebut disebut sebagai putusan BPSK. (Pasal 38 Kepmenperindag No. 350/MPP/Kep/12/2001).

Putusan BPSK dapat berupa perdamaian, gugatan ditolak, atau gugatan dikabulkan. Dalam hal gugatan dikabulkan, maka dalam amar putusan ditetapkan kewajiban yang harus dilakukan oleh pelaku usaha berupa pemenuhan ganti rugi (pengembalian uang, penggantian barang dan atau jasa yang sejenis atau setara nilainya, atau perawatan kesehatan dan atau pemberian santunan) dan atau sanksi administratif berupa penetapan ganti rugi paling banyak Rp.200.000.000,00 (dua ratus juta rupiah).

Agar lebih jelas, berikut ini akan dijabarkan tentang tata cara penyelesaian sengketa melalui BPSK, yaitu sebagai berikut: ${ }^{18}$

\section{a. Penyelesaian Sengketa BPSK dengan Mediasi}

1) BPSK membentuk sebuah fungsi badan sebagai fasilitator yang aktif untuk memberikan petunjuk, nasehat dan saran kepada yang bermasalah;

18 Direktorat Perlindungan Konsumen, Direktorat Jenderal Perdagangan Dalam Negeri., 2003. 
2) Badan ini membiarkan yang bermasalah menyelesaikan permasalahan mereka secara menyeluruh untuk bentuk dan jumlah konpensasinya;

3) Ketika sebuah penyelesaian dicapai, itu akan diletakkan pada persetujuan rekonsiliasi yang diperkuat oleh putusan BPSK;

4) Penyelesaian dilaksanakan paling lambat 21 (dua puluh satu) hari kerja.

\section{b. Penyelesaian Sengketa BPSK dengan Konsiliasi}

1) BPSK membentuk sebuah badan sebagai pasif fasilitator;

2) Badan ini membiarkan yang bermasalah menyelesaikan permasalahan mereka secara menyeluruh untuk bentuk dan jumlah konpensasinya;

3) Ketika sebuah penyelesaian dicapai, itu akan diletakkan pada persetujuan rekonsiliasi yang diperkuat oleh putusan BPSK;

4) Penyelesaian dilaksanakan paling lambat 21 (dua puluh satu) hari kerja.

\section{c. Penyelesaian sengketa BPSK dengan Arbitrase}

1) Para pihak yang bermasalah memilih badan CDSB sebagai arbiter dalam menyelesaikan masalah konsumen

2) Kedua belah pihak seutuhkan membiarkan badan tersebut menyelesaikan permasalahan mereka.

3) BPSK membuat sebuah penyelesaian final yang mengikat

4) Penyelesaian harus diselesaikan dalam jangka waktu 21 hari kerja paling lama.

5) Ketika kedua belah pihak tidak puas pada penyelesaian tersebut, kedua belah pihak dapat mengajukan keluhan kepada Pengadilan Negeri dalam 14 hari setelah penyelesaian di informasikan.

6) Tuntutan kedua belah pihak harus dipenuhi dengan persyaratan sebagai berikut:

a) Surat atau dokumen yang diberikan ke Pengadilan adalah diakui atau dituntut salah/palsu

b) Dokumen penting ditemukan dan disembunyikan oleh lawan; atau

c) Penyelesaian dilakukan melalui satu dari tipuan pihak dalam investigasi permasalahan di pengadilan.

7) Pengadilan Negeri dari badan peradilan berkewajiban memberikan penyelesaian dalam waktu 21 hari kerja

8) Jika kedua belah pihak tidak puas pada keputusan pengadilan/penyelesaian, mereka tetap memberikan kesempatan untuk mendapatkan sebuah kekuatan hukum yang cepat kepada pengadilan mahkamah Agung dalam jangka waktu 14 hari 
9) Mahkamah Agung berkewajiban memberikan penyelesaian dalam jangka waktu 30 hari.

Adapun alur atau skema penyelesaian sengketa konsumen melalui BPSK dapat digambarkan seperti pada skema di bawah ini.

\section{Skema I:}

\section{Alur Penyelesaian sengketa konsumen melalui BPSK}

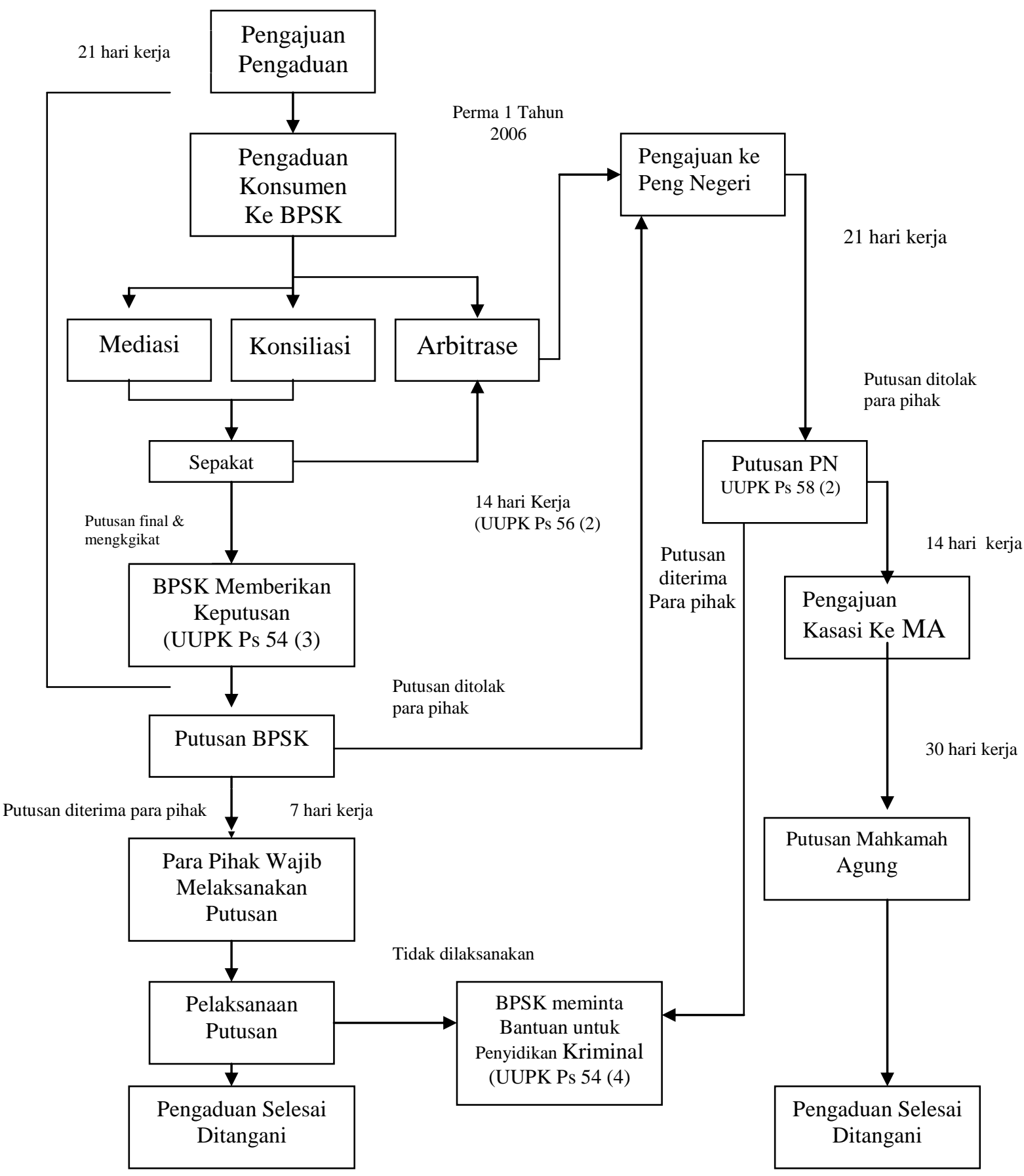




\section{Penyelesaian sengketa Konsumen di Negara-negara Common Law System}

Di beberapa Negara yang menganut Common Law System, kasuskasus penyelesaian sengketa konsumen diselesaikan oleh lembaga yang disebut The Small Claims Court, The Small Claims Tribunal, The Consumer Claims Tribunal dan The Market Court.

Lembaga penyelesaian sengketa ini pada umumnya terdapat di negara-negara, yaitu:

a. The Small Claims Court terdapat di Negara Amerika Serikat dan Singapura;

b. The Small Claims Tribunal terdapat di Negara New Zealand, Singapura dan Hongkong;

c. The Consumer Claims Tribunal terdapat di Negara Australia; dan

d. The Market Court terdapat di Negara Finlandia dan Swedia.

e. Consumer Disputes Redressal Agencies/District Forum, terdapat di Negara India.

Dari ke empat istilah penyelesaian sengketa ini, secara garis besar dapat dikelompokkan menjadi 2 (dua) yaitu:

\section{Small Claims Court (SCC)}

Model penyelesaian sengketa Small Claims court merupakan sistim penyelesaian yang sederhana yaitu hakim tunggal, tanpa juri dan pembuktian yang sederhana. Pada perkara small calim court ini, umumnya tidak dipakai jasa penasehat hukum, tetapi dimungkinkan bantuan dari relasi, teman atau lay representative yang dapat diminta dari Citizens Advice Bureau, yang mempunyai trained advisers yang siap membantu mereka yang mengajukan gugatan kecil.

Model penyelesaian sengketa The Small Claims Court memiliki ciriciri sebagai berikut, yaitu:

a. Pada umumnya merupakan bagian dari sistem peradilan atau peradilan khusus di luar sistem peradilan yang bersifat independent.

b. Terdapat batasan mengenai kasus apa saja yang dapat diajukan atau tidak dapat diajukan pada Small Claims Court maupun Small Claims Tribunal.

c. Terdapat batasan nilai gugatan. Pada umumnya yang dapat diajukan adalah sengketa yang nilai gugatannya kecil.

d. Biaya perkara yang lebih rendah dibandingkan biaya perkara yang diajukan pada pengadilan. Bahkan dari beberapa negara dibebaskan dari biaya perkara.

e. Prosedur yang sederhana dan lebih bersifat informal sehingga para pihak yang awam hukumpun dapat mengajukan sendiri.

f. Proses pemeriksaannya berlangsung cepat dan tidak berbelitbelit. 
g. Dengan prosedur yang cepat, sederhana dan biaya ringan tersebut, maka para pihak yang berperkara tidak memerlukan bantuan seorang advokat/penasihat hukum.

h. Alternatif penyelesaian sengketa lebih terbuka, dalam arti tidak selalu tergantung pada pertimbangan hakim berdasarkan hukum formal yang berlaku, namun dimungkinkan sebuah putusan yang didasarkan pada tawar menawar para pihak yang difasilitasi hakim.

i. Pada umumnya Small Claims Court atau Small Claims Tribunal, memeriksa, mengadili dan memutus tuntutan yang berupa uang ganti kerugian yang bersifat materil, sekalipun dimungkinkan pula tuntutan dalam bentuk yang lain, misalnya permintaan maaf.

\section{Small Claims Tribunal (SCT)}

The Small Claims Tribunal, dipergunakan untuk menyebut sebuah lembaga penyelesaian perkara perdata (civil claims) berskala kecil dengan cara sederhana, tidak formal, cepat dan biaya murah. Lembaga penyelesaian sengketa ini pada umumnya terdapat di negara-negara yang menganut sistem hukum Anglo saxon atau common law seperti: New Zealand, Hongkong, dan Singapura.

Seperti halnya The Small Claims Court, The Small Claims Tribunal juga memiliki ciri-ciri dan karekteristik , yaitu: ${ }^{19}$

a. Pada umumnya merupakan bagian dari sistem peradilan atau peradilan khusus di luar sistem peradilan yang bersifat independent.

b. Terdapat batasan mengenai kasus apa saja yang dapat diajukan atau tidak dapat diajukan pada Small Claims Court maupun Small Claims Tribunal.

c. Terdapat batasan nilai gugatan. Pada umumnya yang dapat diajukan adalah sengketa yang nilai gugatannya kecil.

d. Biaya perkara yang lebih rendah dibandingkan biaya perkara yang diajukan pada pengadilan. Bahkan dari beberapa negara dibebaskan dari biaya perkara

e. Prosedur yang sederhana dan lebih bersifat informal sehingga para pihak yang awam hukumpun dapat mengajukan sendiri.

f. Proses pemeriksaannya berlangsung cepat dan tidak berbelitbelit.

g. Dengan prosedur yang cepat, sederhana dan biaya ringan tersebut, maka para pihak yang berperkara tidak memerlukan bantuan seorang advokat/penasihat hukum.

${ }^{19}$ Susanti Adi Nugroho, "Proses Penyelesaian Sengketa Konsumen Ditinjau Dari Hukum Acara Serta Implementasinya", (Jakarta: Kencana, 2008), hal. 87. 
h. Alternatif penyelesaian sengketa lebih terbuka, dalam arti tidak selalu tergantung pada pertimbangan hakim berdasarkan hukum formal yang berlaku, namun dimungkinkan sebuah putusan yang didasarkan pada tawar menawar para pihak yang difasilitasi hakim.

i. Pada umumnya Small Claims Court atau Small Claims Tribunal, memeriksa, mengadili dan memutus tuntutan yang berupa uang ganti kerugian yang bersifat materil, sekalipun dimungkinkan pula tuntutan dalam bentuk yang lain, misalnya permintaan maaf.

Di Negara Singapura, pada penyelesaian sengketa konsumen dengan The Small Claims Tribunal yang bertindak sebagai hakim adalah seorang Barrister atau Salicitor sebagai Referee. Anggota tribunan yang memimpin jalannya persidangan disebut dengan istilah "President" sebagai konsekuensinya putusannya hanya disebut dengan istilah "decision" atau "settlement" atau "award". Singapura sebagai negara yang menggunakan The Small Claims Tribunal memberikan batasan mengenai gugatan yang dapat diajukan yaitu kerugian dialami konsumen tidak lebih dari Sin\$ 2000. (Dolar Singapura). ${ }^{20}$

Perbedaan mendasar antara kedua jenis penyelesaian sengketa ini adalah Small Claims Court (SCC) bersifat tetap sedangkan Small Claims Tribunal (SCT) bersifat sementara atau ad hoc. Hal ini tampak dalam kewenangan untuk memeriksa, mengadili dan menjatuhkan putusan atau dengan kata lain yang bertindak sebagai hakim pada Small Claims Court benar-benar dijalankan oleh seorang hakim (presiding judge) sehingga putusannya disebut judgement. ${ }^{21}$

\section{Perbedaan Penyelesaian sengketa melaui BPSK dengan SCC dan SCT}

Penyelesaian sengketa konsumen di Indonesia melalui melalui BPSK, memiliki perbedaan dengan penyelesaian sengketa konsumen di negara-negara common law system dengan model Small Claims Court dan Small Claims Tribunal (SCT). Perbedaan tersebut sebagaimana terlhat di negara India yaitu sebagai berikut: ${ }^{22}$

${ }^{20}$ Catherine Tay Swee Kian \& Tang See Chim, "Your Right as a Consumer", (Singapura: Penerbit, Time Book International, 1986), hal. 109.

\footnotetext{
${ }^{21}$ Susanti Adi Nugroho, Op.Cit., hal. 86.

${ }^{22}$ Ibid.
} 
a. Sengketa konsumen di India hanya dimungkinkan satu kali banding sedangkan BPSK dimungkinkan dua kali banding yaitu, keberatan ke Pengadilan Negeri dan kasasi ke mahkamah Agung;

b. Anggota majelis penyelesaian sengketa konsumen di India adalah gabungan dari hakim aktif maupun pensiunan hakim dan komponen masyarakat, sedangkan majelis BPSK terdiri dari unsur pemerintah, unsur konsumen dan unsur pelaku usaha.

c. Di India tingkat penyelesaian sengketa yang dikaitkan dengan jumlah nilai gugatan, sedangkan di Indonesia tidak dikaitkan dengan batas jumlah tuntutan. Itu berarti lembaga BPSK berkewajiban untuk menyelesaikan sengketa dengan nilai gugatan yang tidak terbatas. Tugas dan kewajiban BPSK untuk melayani semua sengketa konsumen dengan model penyelesaian sengketa melalui mediasi, konsiliasi dan arbitrase. Hal ini memperlihatkan bahwa lembaga BPSK ini bukan merupakan suatu model Small Claim Court untuk menyelesaikan sengketa konsumen dengan nilai yang kecil, seperti maksud semula pembentukan BPSK.

d. Lembaga penyelesaian sengketa konsumen di India, mempunyai tugas dan kewenangan hanya menyelesaikan sengketa konsumen, sedangkan BPSK selaian menyelesaikan sengketa konsumen juga mempunyai kewenangan mengawasi klausula baku. Menurut penulis salah satu persoalan yang muncul dalam sistem perlindungan konsumen adalah ketidakjelasan sistematika kewenangan antar lembaga atau institusi. Sehingga kedepan, tugas pengawasan terhadap klausula baku, yang sifatnya preventif (bukan sengketa) akan lebih tepat kalau menjadi kewenangan penuh Badan Perlindungan Konsumen Nasional (BPKN).

Untul lebih jelasnya, berikut ini penulis digambarkan dalam bentuk tabel, perbedaan antara Penyelesaian sengketa di Indonesia melalui BPSK dengan penyelesaian sengketa konsumen di negara-negara common law system melalui Small Claims Court (SCC) sebagaimana berlaku di Negara India.

Tabel 1 : Perbedaan BPSK dengan Small Claims Court (SCC) di India

\begin{tabular}{|l|l|l|}
\hline No & \multicolumn{1}{|c|}{ BPSK } & \multicolumn{1}{|c|}{ Small Calims Court (SCC) } \\
\hline 1. & $\begin{array}{l}\text { BPSK dimungkinkan dua kali } \\
\text { banding yaitu, keberatan ke } \\
\text { Pengadilan Negeri dan kasasi } \\
\text { ke Mahkamah Agung }\end{array}$ & $\begin{array}{l}\text { Sengketa konsumen di India hanya } \\
\text { dimungkinkan satu kali banding }\end{array}$ \\
\hline 2. & $\begin{array}{l}\text { Majelis BPSK terdiri dari } \\
\text { unsur pemerintah, unsur } \\
\text { konsumen dan unsur pelaku } \\
\text { usaha }\end{array}$ & $\begin{array}{l}\text { Anggota majelis penyelesaian } \\
\text { sengketa konsumen di India adalah } \\
\text { gabungan dari hakim aktif maupun } \\
\text { pensiunan hakim dan komponen } \\
\text { masyarakat }\end{array}$ \\
\hline 3. & $\begin{array}{l}\text { Pada BPSK tidak dikaitkan } \\
\text { dengan batas jumlah tuntutan. }\end{array}$ & $\begin{array}{l}\text { Di India tingkat penyelesaian } \\
\text { sengketa yang dikaitkan dengan }\end{array}$ \\
\hline
\end{tabular}




\begin{tabular}{|c|c|c|}
\hline & & jumlah nilai gugatan \\
\hline 3. & $\begin{array}{lr}\text { BPSK selaian menyelesaikan } \\
\text { sengketa konsumen juga } \\
\text { mempunyai k kewenangan } \\
\text { mengawasi klausula baku }\end{array}$ & $\begin{array}{l}\text { Lembaga penyelesaian sengketa } \\
\text { konsumen di India, mempunyai } \\
\text { tugas dan kewenangan hanya } \\
\text { memnyelesaikan } \\
\text { konsumen }\end{array}$ \\
\hline
\end{tabular}

Sumber: data primer diolah penulis

Adapun perbedaan secara umum antara penyelesaian sengketa konsumen di Indonesia melalui BPSK dengan penyelesaian sengketa di negara-negara common law system melalui Small Claims Tribunal (SCT) yang berlaku di negara Common Law adalah sebagai berikut:

Tabel 2 : Perbedaan BPSK dengan Small Claims Tribunal (SCT)

\begin{tabular}{|c|c|c|}
\hline No & BPSK & Small Claims Tribunal (SCT) \\
\hline 1. & $\begin{array}{l}\text { BPSK adalah lembaga } \\
\text { penyelesaian sengketa konsumen } \\
\text { berskala kecil, formal dan biaya } \\
\text { murah. }\end{array}$ & $\begin{array}{l}\text { SCT adalah lembaga penyelesaian } \\
\text { perkara perdata (civil claims) } \\
\text { berskala kecil dengan cara } \\
\text { sederhana, tidak formal, cepat dan } \\
\text { biaya murah }\end{array}$ \\
\hline 2. & tap & $\begin{array}{l}\text { Small Claims Tribunal bersifat } \\
\text { sementara atau ad hoc }\end{array}$ \\
\hline 3. & $\begin{array}{l}\text { Pada BPSK yang bertindak } \\
\text { sebagai hakim adalah anggota } \\
\text { BPSK yang berasal dari unsur } \\
\text { pemerintah, unsur konsumen dan } \\
\text { unsur pelaku usaha. }\end{array}$ & $\begin{array}{l}\text { Pada The Small Claims Tribunal } \\
\text { yang bertindak sebagai hakim } \\
\text { adalah seorang Barrister atau } \\
\text { Salicitor sebagai Referee }\end{array}$ \\
\hline 4. & $\begin{array}{l}\text { Anggota BPSK yang memimpin } \\
\text { persidangan disebut Ketua } \\
\text { Majelis BPSK. }\end{array}$ & $\begin{array}{l}\text { Anggota tribunan yang memimpin } \\
\text { jalannya persidangan disebut } \\
\text { dengan istilah "President" sebagai } \\
\text { konsekuensinya putusannya hanya } \\
\text { disebut dengan istilah "decision" } \\
\text { atau "settlement" atau "award". }\end{array}$ \\
\hline 5 . & $\begin{array}{c}\text { nilai ke } \\
\text { ang dapat }\end{array}$ & $\begin{array}{l}\text { The Small Claims Tribunal } \\
\text { memberikan batasan mengenai } \\
\text { gugatan yang dapat diajukan yaitu } \\
\text { kerugian dialami konsumen tidak } \\
\text { lebih dari Sin\$ 2000. (Dolar } \\
\text { Singapura) }\end{array}$ \\
\hline 6. & $\begin{array}{l}\text { BPSK menyelesaikan kasus- } \\
\text { kasus sengketa konsumen dan } \\
\text { pelanggaran pelaku usaha atas } \\
\text { klausula baku. }\end{array}$ & $\begin{array}{l}\text { Terdapat batasan mengenai kasus } \\
\text { apa saja yang dapat diajukan atau } \\
\text { tidak dapat diajukan pada Small } \\
\text { Claims Court maupun Small } \\
\text { Claims Tribunal }\end{array}$ \\
\hline 7 & $\begin{array}{l}\text { aya perkara d } \\
\text { aku usaha. }\end{array}$ & $\begin{array}{l}\text { Biaya perkara rendah bahkan } \\
\text { dibeberapa negara di bebaskan }\end{array}$ \\
\hline
\end{tabular}


Sumber: data primer diolah penulis

Dari perbedaan antara BPSK dengan Small Claims Tribunal (SCT) dan Small Claims Court (SCC) di atas, tampak bahwa penyelesaian sengketa konsumen di Indonesian melalui BPSK tidak konsisten, hal ini disebabkan karena beberapa hal yaitu sebagai berikut:

a. Apabila dibandingkan dengan Small Claims Court (SCC), BPSK memiliki tugas yang sangat banyak. Hal ini menurut penulis yang menyebabkan BPSK menjadi tidak fokus dalam melaksanakan pekerjaannya, sehingga ke depan tugas BPSK harus difokuskan pada penyelesaian sengketa saja sesuai dengan namanya yaitu Badan Penyelesaian Sengketa Konsumen.

b. BPSK adalah lembaga penyelesaian sengketa konsumen berskala kecil, formal dan biaya murah. Namun, dalam implementasinya BPSK tidak memberikan batasan mengenai nilai kerugian atau gugatan yang dapat diajukan ke BPSK. Berbeda dengan Small Claims Tribunal yang memberikan batasan yang jelas mengenai gugatan yang dapat diajukan, misalnya di Singapura kerugian konsumen yang ditangani tidak lebih dari 2000 dolar.

c. Pada Small Claims Court (SCC) Majelis yang menyelesaikan perkara berasal dari unsur hakim aktif dan pensiunan, sedangkan pada BPSK majelis berasal dari unsur pemerintah, pelaku usaha dan konsumen dengan latar belakang yang berbeda-beda. Penulis berpendapat, ke depan anggota Majelis BPSK harus berasal dari unsur akademisi, pelaku usaha dan konsumen dengan latar belakang pendidikan Sarjana Hukum (SH) sehingga akan lebih memahami tugas-tugas dalam bidang peradilan.

\section{Penutup}

\section{Simpulan}

Dari pembahasan yang sudah dipaparkan di atas dapat ditarik simpulan yaitu perbedaan penyelesaian sengketa konsumen melalui BPSK di Indonesia dengan penyelesaian sengketa konsumen model SCC dan SCT di negara-negara common law system dapat dilihat dari kelembagaan, batasan nilai gugatan, dan asal majelis (hakim). BPSK merupakan lembaga penyelesaian sengketa konsumen yang berskala kecil, formal dan biaya murah, namun tidak membatasi besar gugatan yang diajukan konsumen, sedangkan SCT merupakan lembaga penyelesaian perkara perdata (civil claims) berskala kecil dengan cara sederhana, tidak formal, cepat dan biaya murah serta memberikan batasan yang jelas mengenai gugatan yang dapat diajukan oleh konsumen. Pada penyelesaian model SCC, majelis yang menyelesaikan 
perkara berasal dari unsur hakim aktif dan pensiunan, sedangkan pada BPSK majelis berasal dari unsur pemerintah, pelaku usaha dan konsumen dengan latar belakang yang berbeda-beda.

\section{Saran}

BPSK di Indonesia merupakan adopsi dari model Small Claim Tribunal (SCT) yang sudah berjalan di negara-negara maju atau penganut common law system, namun dalam implementasinya banyak konsepkonsep SCT yang tidak diterapkan pada BPSK. Kedepan sebaiknya BPSK menerapkan ketentuan seperti yang ada dalam SCT terutama mengenai pembatasan nilai gugatan konsumen. Selain itu, anggota BPSK sebaiknya berasal dari unsur di luar pemerintah agar lebih independen serta berpendidikan Sarjana Hukum. 


\section{Daftar Pustaka}

\section{Buku}

Ali, Ahmad. Sosiologi Hukum: Kajian Empiris Terhadap Pengadilan, Jakarta: Iblam, 2004.

Cristoper W. Moore. The Mediation Process: Practical Strategies for Resolving Conflict (Edisi Kedua), San Francisco: Jossey-Bass Publishers, 1996.

Swee Kian, Catherine Tay \& Tang See Chim, Your Right as a Consumer, Singapura: Time Book International, 1986.

Ihromi. Beberapa Catatan Mengenai Metode Sengketa yang Digunakan Dalam Antropologi Hukum, dalam Antropologi Hukum; Sebuah Bunga Rampai, Jakarta: Yayasan Obor, 1993.

Kurniawan. Hukum Perlindungan Konsumen, Problematika Kedudukan dan Kekuatan Putusan BPSK, Malang: UB Press, 2011.

Marbun, B.N. Kamus Hukum Indonesia, Cetakan I, Jakarta: Pustaka Sinar Harapan, 2006.

Munir, Mochamad. Penggunaan Pengadilan Negeri Sebagai Lembaga Untuk Menyelesaikan Sengketa Dalam Masyarakat (Disertasi Universitas Airlangga Surabaya), 1997.

Nugroho, Susanti Adi. Proses Penyelesaian Sengketa Konsumen Ditinjau Dari Hukum Acara Serta Implementasinya, Jakarta: Kencana, 2008.

Rohmad, Abu. Paradigma Resolusi Konflik Agraria, Semarang: Walisongo Press, 2008.

Simorangkir. J.C.T., et.al, Kamus Hukum, Cetakan ke-5, Jakarta: Bumi Aksara, 1995.

Syafa'at, Rachmad. Mediasi dan Advokasi Konsep dan Implementasinya, Malang: Agritek YPN Malang Kerjasama dengan SOFA Press, 2006.

\section{Artikel-Artikel/Internet/Makalah}

Deperindag. Pedoman Operasional Badan Penyelesaian Sengketa Konsumen (BPSK), 2003.

Deperindag. Pedoman Pembentukan Badan Penyelesaian Sengketa Konsumen (BPSK), 2002.

Direktorat Perlindungan Konsumen. Direktorat Jenderal Perdagangan Dalam Negeri, 2003.

Kurniawan. "Penyelesaian Sengketa Konsumen Melalui BPSK di Indonesia (Kajian Yuridis Terhadap Permasalahan dan Kendala-kendala BPSK)", 
Jurnal Hukum \& Pembangunan, Fakultas Hukum Universitas Indonesia, Tahun Ke-41 No. 3 Juli 2011.

Suparman, Eman. Jurisdiksi Pengadilan Negeri Terhadap Forum Arbitrase

Dalam Penyelesaian Sengketa Bisnis Berdasarkan Undang-undang Nomor 30 Tahun 1999, Laporan Hasil Penelitian, Dana DIK UNPAD 2003.

\section{Perundang-Undangan}

Undang-Undang Nomor 8 Tahun 1999 tentang Perlindungan Konsumen (Lembaran Negara RI Tahun 1999 Nomor 42, Tambahan Lembaran Negara RI No. 3821).

Undang-Undang Nomor 30 Tahun 1999 tentang Arbitrase dan Alterlatif Penyelesaian Sengketa (Lembaran Nebara RI Tahun 1999 Nomor 138, Tambahan Lembaran Negara Nomor 3872).

Keputusan Presiden Nomor 90 Tahun 2001 tentang Pembentukan BPSK pada Pemerintah Kota Medan, Kota Palembang, Kota Jakarta Pusat, Kota Jakarta Barat, Kota Bandung, Kota Semarang, Kota Yogyakarta, Kota Surabaya, Kota Malang dan Kota Makassar.

Keputusan Menteri Perindustrian Nomor 350/MPP/Kep/12/2001 tentang Pelaksanaan Tugas dan Weweang Badan Penyelesaian Sengketa Konsumen. 